\title{
Revisiting the role of woman pastors in the church in Tshwane
}

\author{
Author: \\ Elizabeth C. Wagner-Ferreira ${ }^{1}$ \\ Affiliation: \\ ${ }^{1}$ Department of Practical \\ Theology, University of \\ South Africa, South Africa \\ Note: \\ Part of this research was \\ presented at a workshop \\ at the Society of Practical \\ Theology on 22 January \\ 2010 at the University of \\ Pretoria, South Africa. \\ Correspondence to: \\ Bettie Wagner-Ferreira \\ email: \\ wagneec@unisa.ac.za \\ Postal address: \\ PO Box 26697, \\ Monumentpark 0105, \\ South Africa \\ Dates: \\ Received: 02 Aug. 2010 \\ Accepted: 17 Feb. 2011 \\ Published: 21 Apr. 2011 \\ How to cite this article: \\ Wagner-Ferreira, E.C., \\ 2011, 'Revisiting the role \\ of woman pastors in \\ the church in Tshwane' \\ HTS Teologiese Studies/ \\ Theological Studies 67(2), \\ Art. \#932, 7 pages. DOI: \\ 10.4102/hts.v67i2.932
}

The purpose of this article was to obtain feedback from women pastors in and around the Tshwane metropole in South Africa on their experiences of their role as pastors. The question at stake was: are woman pastors more often approached for counselling? Therefore, half structured interviews were conducted in order to explore their life stories. The four core tasks of practical theological interpretation, according to Richard Osmer, were used as the framework for this article.

\section{Introduction}

In a number of churches, women pastors are a well-known phenomenon. Some of the younger generation of church members might not even be aware that there was a time when women were not allowed to be pastors in churches.

According to an article in Beeld (20 August 2009), woman pastors seem to be more aware and involved with counselling in cases of abuse against women and in families than their male colleagues. This article reported on discussions of the task team for diversity of the general synod of the Dutch Reformed Church (DRC) at Achterberg on 18-19 Augustus 2009.

In the South African context, it is well-known that a number of woman and children are being abused. What is the role of the woman pastors in counselling and supporting the victims of abuse? Do woman pastors in churches other than the DRC also experience that they are approached more often by abused woman and children?

Narrative research (data was gathered through the stories of individuals) was used to obtain information regarding the role of the woman pastor in a church and specifically to hear their stories about their involvement in counselling. A conceptual framework was structured from the literature study that was done.

The goal of this research was to get an impression whether woman pastors experience that they are approached more often for counselling by church members and to see if there are possibilities for future research in this regard. Therefore, interviews were conducted with full-time woman ministers in the Tshwane metropole (where I reside). During the interviews, woman pastors shared their life stories according to the following question: 'How do woman pastors experience their role in the church?' This broad question gave the pastors the opportunity to share their experiences before the interview focused more particularly on counselling.

The aspect of confidentiality was very important for most of the participants. As one pastor put it, she 'does not want to be labelled'. From the first contact that was made, namely the telephonic conversation where the pastors were approached to take part in the research project, confidentiality was discussed. During the interviews, the participants were cautious, although all of them were willing to share their experiences. The interviews were recorded and it happened quite often that after the tape recorder was switched off much more information was given. This reaction, amongst others, underlined the cautiousness of the participants.

'What is going on here and why is it going on?' are the questions that were asked. Richard Osmer (2008) asked the same questions in his book, Practical Theology: An Introduction, four core tasks of practical theological interpretation. Therefore, it was decided to use this as a basic structure for the research.

Although women are allowed to be ministers in a number of churches, there are still some churches that do not approve of women in full-time ministry. It is not the purpose of this research to get involved in the interpretation of the Bible or in the different churches' perspectives that indicate whether women should or should not be allowed to be full time pastors. Therefore, it will not be discussed any further. 


\section{The four tasks of practical theological interpretation according to Richard Osmer}

Richard Osmer (2008:4) indicated that four questions can guide one's interpretation and response in research from a practical theological point of view:

- What is going on?

- Why is this going on?

- What ought to be going on?

- How might we respond?

Answering these questions is the focus of the four core tasks of practical theological interpretation. The four tasks are (Osmer 2008:4):

- the descriptive-empirical task (gathering information that helps us discern patterns and dynamics in particular episodes, situations or contexts)

- the interpretive task (make use of theories to better understand and explain why these patterns and dynamics are occurring)

- the normative task (use theological concepts to interpret particular episodes, situations or contexts, constructing ethical norms to guide our responses and learning from 'good practice')

- the pragmatic task (determining strategies of action that will influence situations in ways that are desirable and entering into a reflective conversation with the 'talk back' emerging when they are enacted).

Together, these four tasks constitute the basic structure of practical theological interpretation and were used as foundation for this article. A metatheoretical perspective is composed of the assumptions about reality, knowledge and science that transcend particular research projects and theories (Osmer 2008:58).

\section{The descriptive-empirical task}

The descriptive-empirical task of practical theological interpretation is grounded in a spirituality of presence. Here, attention is given to what is going on in the lives of individuals (Osmer 2008:34). Information is gathered in order to discern patterns and dynamics. Empirical research is helpful to recognise social trends or patterns that are impacting people's lives and shaping the context of ministry (Osmer 2008:41). Dreyer (2009:23) emphasises that in order to establish the truth in empirical theology 'both participation and distanciation in a never-ending process of learning and developing the craft of doing empirical theology' is important. Without participation, acknowledging research participants and the researcher as a human being in interaction with one another, our worlds, our prejudices in both qualitative and quantitative empirical theological research, the search for truth may be an illusion (cf. Dreyer 2009:6; Alvesson 2002:2).

The information given previously was gathered through listening to the 'life history' (Osmer 2008:50) of full-time woman pastors. Data was gathered through interviews where they shared stories and events. The researcher listened for and drew out competing stories from what was said and confirmed the interpretations with the participants in order to give them the opportunity to revise the narrative constructing (Osmer 2008:51).

The life stories of women pastors and the literature study was used in order to bring some perspectives on the question: What is going on in this situation? (Are woman pastors more involved in counselling?)

The only criterion that was used for the selection of the participants was that the women should be full-time pastors in the Tshwane metropole (the greater Pretoria area). The goal was to determine whether woman pastors from other churches experience the same that the article in Beeld mentioned about the experiences of the women pastors in the DRC. The participants were from the following churches: Apostolic Faith Mission, Anglican Church, DRC, Emmanuel Church (independent church), Methodist Church and the Nederduitsch Hervormde Kerk.

The interviews were listened to and the following themes were identified from the life stories of the woman pastors: context, role expectations and role concepts.

For the second task of practical theological interpretation, namely the interpretive task, Osmer (2008:7) draws on theories to better understand and explain why certain events occur.

\section{The interpretive task}

Throughout the modern period, reflection on interpretation was associated with the field of hermeneutics. Hermeneutics focused initially on the art and science of the interpretation of ancient texts. It expanded in the 20th century in two ways:

(1) hermeneutics was broadened to include the interpretive activity of ordinary people in everyday life; (2) it was recognized as a dimension of all forms of scholarships, the hermeneutical or interpretive dimension of the sciences and humanities.

(Osmer 2008:20-21)

Gadamar argued, as did Heidegger, that all interpretations begin in an already-interpreted world. He particularly indicated that all interpretations begin with preunderstandings that come to us from the past (cf. Gadamar 1975).

This takes the form of research traditions that provide scientists with a language, conceptual framework and research practices with which to begin their inquiries. Rather than pretending to bracket out all pre-understandings in the futile attempt to hold a neutral, objective point of view, it is better to acknowledge their interpretive starting point, the particular research tradition that guides their work (Osmer 2008:22). The pre-understanding with which we begin interpretation does not necessarily determine the end point of interpretation. He developed the important concept of 'hermeneutical experience' to describe the sort of interpretive 
activity that is open to encountering and learning something new (Osmer 2008:22-23).

Osmer (2008:48-53) indicated that clarity about the purpose of the research and strategies for inquiry is important. The purpose of this preliminary research was to get an indication from woman pastors (from different churches) whether they also experience that their churches expect of them to focus more on counselling.

The strategy used was life history or narrative research. This strategy of inquiry focused on gathering information and telling stories (Osmer 2008:50-51). During the interviews conducted with the woman pastors, they shared their life stories. The pastors were given the opportunity so share several incidents on their experience regarding the congregation's role expectations and role concepts in their context.

The literature study was done to enlighten the themes that were constructed from the life stories.

\section{Context}

The context is composed of the social and natural systems in which a situation unfolds. Context serves a flexible purpose calling attention to micro systems and macro systems that are relevant to a given case. Contextual analysis is therefore an important dimension of practical theological interpretation (Osmer 2008:12).

The context regarding the churches in South Africa (of which Tshwane is part of) face many new challenges, for example, the demographic changes, the challenge of transformation and finding their role and function in a new political dispensation, the challenge of poverty and growing inequality (cf. Erasmus, Gouws \& Van der Merwe 2009:9).

The challenges are not only from within South Africa, but world events have also had an influence on the South African context. Here, one can think about the events of the past few years, for example: floundering world economics, corporate financial scandals, recessions and downsizings as well as the explosion of information technology. The psychological fallout from the attacks of 11 September 2001 and the threat of terrorism in the world add on to these dynamics. The uncertainty and emotional concerns put a great deal of pressure on leadership in general. It is expected that the modern church leader will have the ability to understand the complex and varied impacts that difficult times have on people and to provide authentic and empathetic leadership that facilitates healing, revitalisation and commitment in others. Therefore, the bar has been raised for church leaders, both male and female. People expect that leaders will be equally or even more proficient in the 'soft' leadership skills. People count on leaders to mentor, coach and model attributes such as honesty, integrity, energy, trust, intuition, imagination, empathy and humility (cf. Bunker \& Wakefield 2004:17-19).
In the South African context, the move to secularisation has become more evident. Analysing religious data from national censuses of South Africa and the World Values Surveys indicates that 'No religion' increased from 1.2\% in 1991 to $15.1 \%$ in 2001. Thus, in the new South Africa, the tendency towards not expousing a religion has grown considerably and may indicate the possibility of secularisation of South African communities. Secularisation and privatisation may influence religion and the underlying values thereof are diminishing (cf. Erasmus, Gouws \& Van der Merwe 2009:10 13). This tendency, along with the high levels of violence and HIV and AIDS, puts a great deal of strain on the leadership of churches:

Presently South Africa has one of the highest levels of genderbased violence in the world, one of the highest infection rates with HIV/AIDS globally, and a very serious gap between rich and poor. The poorest $20 \%$ of the population lives in abject poverty. Social welfare in South Africa will have to be gender sensitive in order to deal with these gendered social problems, since culture is often used to justify gender-unequal treatment of women.

(Erasmus, Gouws \& Van der Merwe 2009:24)

The context for pastors can therefore be described as one of transformation, secularisation, uncertainty and high expectations from church members. This was also reflected in the interviews with the woman pastors. All the woman pastors mentioned something about these factors mentioned. The content of the counselling focused on people losing their jobs, children who were raped and murdered, children and young people confronted with gangsterism and drug abuse, as well as people (especially mothers) who is concerned about their children not attending church any more.

In this context there are certain role expectations of spiritual leadership in general.

\section{Role expectations}

Church leaders admit that they are uncertain of their role and responsibilities at this stage. Footprints of postmodernism are evident in churches and communities all over. Members of the church feel 'homeless' in this 'postdenominational era' (cf. Lose 2003:1-2).

Spiritual leadership, in general, differs from the leaders in the secular world. Van Dam (2005:4) indicated the following as possible reason: 'Because of an academic theological education and a spiritual hermeneutic and mystagogical competence'. The pastor is empowered and equipped to listen to the Word of God and able to link the tradition of the Scripture to situations that are relevant today in order to guide people and help them to open up for God who is invisible (cf. Hendriks 2004:197).

During the empirical research, woman pastors mentioned that mothers will come to them after a church sevice with the request to come and 'visit' them and that it was often motivated by the following: 'You are also a mom, you will understand ...' 
Spiritual leaders know that they have to depend on God for guidance and strength (cf. Cilliers 2002:34). Along with this dependency on God, self-knowledge of the pastor is very important. 'Self-analysis gives one insight into one's strengths, limitations and biases' (Hogan 2005:103) and will assist a pastor in his or her work, irrespective of the roleexspections of the members of the church. It may happen that pastors are so over-loaded that they may not have time for their own spiritual life. In this stage, burn-out is a possibility. During burn-out, a desire to spend more time with God may occur. It seems as if pastors need to make a decision for their own spiritual growth, irrespectively of the role expectations (cf. Dreyer 2003:86-87):

It is important that a theological anthropology attempts to integrate all these components: I and self, conscious and unconscious, thinking and feeling as well as certain characteristic styles of conduct in responsible behaviour.

(Louw 1998:203)

The role expectations of a pastor are demanding and an example of this was illustrated through the scenario that played out on the day on which one of the interviews was conducted. The pastor was called out at 05:00 on the morning of the interview to the scene where one of her church members' children was murdered. This happened after she was busy the previous night 'until late' with meetings and counselling. Although she was very weary, the interview continued as it was too difficult to reschedule.

A minister's self-image and his or her culture have an influence on his or her spirituality. On the one hand, pastors need to show through their life's what God can do and on the other hand, the pastor is also part of a secular world. The context of the church also needs to be taken into consideration (cf. Van Dam 2005:7; Nel 2001:14-15). A pastor in growing churches seems to not necessarily be a 'charismatic superstar'. There is growing evidence that a pastor in a growing congregation has a vision for the church and believes that this vision is God-given (Arn 1997:43).

Sweazy (1976:235-236) indicates that pastors should also be clear about their own theology. Theology came from the Greek words theos [God] and leigon [speak], which may indicate something about God who speaks to the church. There are different beliefs in the church today that might be confusing to the members, and in this chaos the church needs a pastor who will interpret the Bible into a common language that is acceptable and understandable to the members of the church. A pastor's theology is usually formed by his or her own experience with God. This seems to correspond with the form of task competence leadership according to Osmer (2008:176).

Osmer (2008:176-178) distinguished three forms of leadership namely, (1) task competence, (2) transactional leadership, and (3) transforming leadership. He described the forms of leadership as follows (Osmer 2008:176-178):

- task competence is the ability to excel in performing the tasks of a leadership role in an organisation
- transactional leadership is the ability to influence others through a process of trade-offs and takes the form of reciprocity and mutual exchange: I will do this for you and in return you will do that for me

- transforming leadership involves 'deep change', leading an organisation through a process in which its identity, mission, culture and operating procedures are fundamentally altered. In a congregation it may change the worship, fellowship, outreach and openness to new members who are different.

From the empirical research that was done, it was clear that the woman pastors focused on people and relationships. Thinking about the forms of leadership that Osmer mentioned above, their form of leadership might be described as transactional leadership.

\section{Role concepts}

In order to try and get more clarification on the role concept of woman pastors, a definition for personality is given, followed by an understanding of the role of woman in society at large. During the interviews with the woman pastors, some of them indicated that they felt that not only gender played a role in their experiences of being approached more often by church members for counselling, but that personality should also be taken into account.

Personality may be described as the integrated and dynamic organisation of an individual's:

psychological, social, moral and physical characteristics as it is coming to the fore in acting towards the community and other people.

(cf. Gouws, Louw, Meyer \& Plug 1979:230)

In the light of this definition, womanhood is part of personality. What it means to be a 'woman' at the beginning of the 21st century differs profoundly from what it meant at the beginning of the 19th century. Gender is not a one dimensional concept, but is always influenced by other markers of difference, such as ethnicity and race, age or ecclesial affiliation, to name but a few. Gender is also coded differently, relative to its ever-changing historical context (cf. Berger 2008:253). It seems that women still face leadership challenges (Ohiott, Bhandary \& Traveres 2003). Krajewski and Burke (2004:172) indicated that 'gender inequality is an aspect of society that continue to draw the attendtion of researcher from a variety of disciplines'.

Whilst there are significant differences between women and men, there may also be some areas that overlap (Glaz 1991:96). There are still some cultures in the African context (Baloyi 2009) with a gender system that emphasise social norms with expectations for appropriate female and male behaviour. According to Louw (2009:293-294), there is a 'gender crisis'. The prescribed gender roles from the 19th century are shaken off and a new kind of gender freedom is established. When one examines gender identity, it becomes clear how closely body, mind and soul are related to each other. The French sociologist Pierre Bourdieu has indicated that it is not the body that presents the objective casual basis for the 
derivation of binary conceptions of gender, but rather the particular cultural conceptions and typologies that crystallise in the experience of corporeality (cf. Karle:2009:252). From this point of view, it seems as if culture has a strong influence on the conceptualisation of gender.

In order to explain the differences between a group of women and a group of men, Jones (2000) distinguished between sex and gender. He refers to sex as the physiological differences between men and women. 'Gender refers to culturally constructed systems of meaning that identify various things - persons, ideas, gods, institutions and so on' (Jones 2000:8). 'Gender applies not only to binary masculinity and femininity, but to all gendered identities' (Berger 2008:252).

In South Africa there are still cultures believing that a gender division of labour exsists in the family, based on the assumption that men are breadwinners and women responsible for caring for the family and domestic labour (Erasmus, Gouws \& Van der Merwe 2009:21; Büchner 2008:243). There are even some communities who believe:

... that womanhood in the African context is strengthened by motherhood. This means that without mothering someone, one cannot be given the title of woman. Being a wife is an expectation while motherhood is a requirement.

(Baloyi 2009:4)

During the interviews, almost all the woman pastors mentioned that they are called by God to 'empower woman'. They also mentioned that they are 'role models' in the church and community.

Fortunately, there are also examples of changes that took place in the South African context, for instance the ordaining of woman as ministers in churches. More than 30 years ago the Algemene Kerkvergadering [General Church meeting] of the Nederduitsch Hervormde Kerk van Afrika were the first to decide that women can also be ministers in the church and after this decision other churches did the same. According to Oliver (2008:213), most of the women pastors still do not experience equality, but even discrimination against them. Oliver's research in the Nederduitsch Hervormde Kerk showed that members of the congregation accept women pastors and behave in the same way towards them as towards their male colleagues. She also found that some woman pastors experienced it as more difficult for male copastors to do the same (Oliver 2008:219-220). She indicated that it might be that they do not know how to act towards women pastors and then they seem to do it in a 'patriarchal' manner (Oliver 2008:226).

'Patriarchy' describes the structure in society where the father is responsible for the welfare of the whole family. The father is the head of his wife and children. He is the person with the power (cf. Buchner 2008:243; Louw 2009:296-297). Patriarchalism emphasises the presence of male power and control in intimate relationships, as well as discrete acts of behaviour (Louw 2009:297). In the church, this behaviour might be illustrated by male church members and ministers who are not willing to share power and want to control all the activities in the church. Five of the seven woman pastors who were interviewed experienced some of this type of behaviour at a certain stage of their ministry and the other two did not experience it themselves, but know of other woman pastors who experienced something similar.

A feministic interpretation of the Bible is one of the approaches that develop over the years in the field of Biblical hermeneutics in reaction against patriarchy:

Along with the development of feminism in general, this approach began in theological circles due to women's growing desire to be liberated from the limitations that the ideology of patriarchy placed on them, not only in society at large, but also in the church.

(Nunes \& Van Deventer 2009:738)

There are many differences amongst feminist Biblical scholars. Some seek to explore Biblical characters, books and themes that are relevant to the modern woman's situation, whilst another group of the feminist Biblical scholars reads the Bible as women, in order to speak up against patriarchy. They want to expose the Bible as a possible tool of oppression against woman (Nunes \& Van Deventer 2009:739). There might also be reformist feminist theologians who have 'almost nothing in common with feminist theologians' (Nunes \& Van Deventer 2009:740). They do not seek to revolutionise Christianity, neither do they want to replace the God as revealed in the flesh by Jesus Christ: 'They are looking for modest changes within existing church structures. They share a commitment to the Christian tradition'. Some indicated that they can solve the problem of women's secondary status with 'measures such as inclusive translations of the Bible and more emphasis on egalitarian passages in the Bible' (Nunes \& Van Deventer 2009:740-741). The last group here described the attitude of all the woman pastors that were interviewed.

From the literature and the empirical research, it is clear that there are many different views on womanhood, especially in the kaleidoscope of diversity in the South African context. The literature study provided the researcher with a language, conceptual framework and research practices to guide the normative task.

\section{The normative task}

These theological concepts mentioned previously were used to interpret particular situations (Osmer 2008:4).

One of the themes in the stories of all the women pastors was their strong feeling about the calling they have from God to be a pastor. 'God called me in full-time ministry' was the response of one participant, which represented all the participants' reaction. This corresponds with the literature that a pastor has a calling to interpret God's word into the lives of people, taking their context into consideration (cf. Van Dam 2005:4; Hendriks 2004:197). Furthermore, the women pastors indicated that God has given them specific gifts in order to fulfill their calling (cf. Theron 1989). The empowerment of women enlighten the literature study, 
where it was mentioned that in the African context, the patriarchal system is still in place in some communities and a woman's value measured only by taking care of the household and bearing children (cf. Baloyi 2009; Erasmus, Gouws \& Van der Merwe 2009; Büchner 2008). From the life stories of the women pastors it was clear that they feel that they can assist other women as rolemodels to realise that they are created according to God's image. The women pastors also feel that they have a special role in the counselling and the assistance of female members in the church.

According to Osmer (2008:193-194), the task competence form of leadership 'involves allowing the concrete needs of those in the community and the well-being of the community as a whole to influence the competencies leaders develop'. Most of the life stories of the woman pastors indicate their commitment to be involved in the well-being of the community. All the respondents indicated that relationships and emotional health are very important in their ministry. Trauma and divorce counselling were some of the topics mentioned when the women pastors conversed about their pastoral care ministry. Some also indicated that motherhood plays an important role in most of the women pastors' ministry as well.

On the whole, the respondents mentioned that gender and personality are interdependent. This corresponds with the definition used for personality. From the interviews, nothing was mentioned about the difference between sex and gender as indicated by Louw (2009) and Jones (2000). Louw (2009:304-305) decided that he wants to 'opt for a theology of embodied intimacy and sensual spirituality'. This option in a practical theology approach implies amongst others the following:

From some-thing to some-body. This paradigm shift is about the personification and ensoulment of the body beyond the cultural limitations of the social classification/role functions of masculinities and femininities. The body is being quality (ontology) and part of our total human dignity as affirmed by the Spirit of God (pneumatology) through the inhabitational presence of God in human corporality.

(Louw 2009:305)

It seems that the women pastors do not differentiate between their personality and gender. It might be that in the South African context this movement as mentioned by Louw and Jones does not have much influence at this time. Pastors are in a relationship with the church members. The woman pastors acknowledged that without a doubt different personalities and personality-styles assist them in their ministry (Steyn 2008:264). The importance and influence of the personalities of pastors and church members may not be underestimated (Steyn 2008). With this empirical research, personality-styles were not researched as an entity.

Another interesting outflow of the empirical research was that about $40 \%$ of the respondents indicated that it might be good to implement a special course or mentorship for women ministers. It seems that there is a need for woman pastors to get more information on the leadership style of males, as well as the way in which they should act towards their male colleagues and male members of the congregation. One respondent indicated that male pastors from her church contacted her to be a mentor to women pastors who are 'cheeky'. With the literature study this concept was not researched at all, but after the interviews it seems to be a topic for further research.

In every woman pastor's life story, it was reflected that she felt she worked harder than her colleagues. Some indicated that they work harder because of their 'perfectionist' personality, whilst others felt that it is expected of them. This reaction was not expected and definitely broadens the focus of the research. It might be interesting to have interviews with church member and get an indication of their experience in this regard.

The life stories of the female ministers gave evidence that most church members approach them for pastoral care. This was illustrated by one respondent, who mentioned that even male members of the congregation with whom she had previously conflict, contacted her when they were in hospital. The women pastors also mentioned positive feedback that they received from church members on their counselling, as well as preaching.

More than half of the women pastors experienced that their male colleagues treated them well. Only two respondents had tremendous conflict with male colleagues. One indicated that since she started as a full-time minister she experienced a great deal of problems. She felt (in her own words) that she was the 'wrong race, the wrong colour, the wrong everything'.

With the normative task, the conversation between theology and other fields is a part of all the tasks of practical theological interpretation. Normative theological perspectives provide interpretive guides with help in determining what they ought to do (pragmatic task).

\section{The pragmatic task}

The pragmatic task focuses on determining strategies of action that will influence situations (Osmer 2008:4) in the practical theological field. The diversity of cultures and different ways of interpreting the behaviour of people was again emphasised in this research. Here, leadership and womanhood were mainly focused on.

\section{Conclusion}

The goal of this article was to get an impression from women pastors from different churches about their role regarding counselling in the church. From the empirical research it was clear that all the women pastors, through sharing their life stories, feel that they make a unique contribution to the counselling in their churches. This preliminary research opens doors for further interviews with more woman pastors, male colleagues and church members to obtain their impressions in this regard. 
In the interviews, a number of pastors mentioned the possibility of a mentoring programme for woman pastors, as well as their experience that they work harder than their colleagues. These themes were something unexpected that came forth from the interviews. It might be interesting to get feedback in this regard as well from more woman pastors, their colleagues and church members.

\section{References}

Alvesson, M., 2002, Postmodernism and Social Research, Open University Press, Buckingham.

Arn, C., 1997, How to start a new service, Baker Books, Michigan.

Baloyi, M.E., 2009, 'Critical reflections on infertility in Black African Christian Communities', Praktiese Teologie in Suid-Afrika 24(2), 1-17.

'Die misbruik en mishandeling van vroue kom baie meer algemeen in gemeentes voor as wat manlike predikante besef', Beeld, 20 August, 2009, n.p.

Berger, T., 2008, 'The challenge of gender for liturgical tradition', Worship 82(3), 243-261.

Botha, J.A, 2009, 'Prosesverslag van die diversiteit taakspan en waarnemers van die Algemene Sinode van die NG Kerk', Achterberg 18-19 Augustus 2009.

Büchner, E.P., 2008, 'Laat ander die praatwerk doen', Studia Historiae Ecclesiaticae XXXIV (April), 235-264

Bunker, K. \& Wakefield, M., 2004, 'In search of authenticity. Now more than ever, soft skills are needed', Lia 24(1), 17-21.

Cilliers, J., 2002, 'Die geheim van die prediking: een-stemmigheid op die kansel', Nederduits Gereformeerde Teologiese Tydskrif 43, 32-38.

Dreyer, D., 2003, Leef jou gemeente regtig?, Lux Verbi.BM, Wellington.

Dreyer, J.S., 2009, 'Establishing truth from participation and distanciation in empirical theology', in J.A. van der Ven (ed.), Empirical Studies in Theology, pp. 3-26, Tuta Sub Aegide Pallas, Brill. doi: 10.1163/ej.9789004168886.i-408.6

Erasmus, J.C., Gouws A. \& Van der Merwe, W., 2009, 'Changing lanscapes of welfare, religion and gender: The impact on the role of the churches', Journal of Theology of Southern Africa 133(March), 8-25.

Gadamar, H.-G., Truth \& method, Sheet \& Ward, London.

Glaz, M., 1991, 'Gender issues in Pastoral Theology', Journal of Patoral Theology 1 (Sum), 93-115.
Gouws, L.A., Louw, D.A., Meyer, W.F., \& Plug, P., 1979, Psigologiewoordeboek, Sigma Press, Pretoria.

Karle, I., 2009, 'Gender norms and their consequences for body and soul - A challenge for the Christian community. From the body as social text (narcissistic model tyranny) to the body as religious text (compassionate intimacy) in practical theology of human embodiment', in W. Grab \& I Charbonnier (eds.), practical theology of human enodizent, Secularization Theroies, Religious Identity and Practical Theology: Developing International Practical Theology for the 21st Century, pp. 252-292, Transaction
Publishers, New Brunswick.

Krajewski, L.A. \& Burke, L.A., 2004, 'A brief commentary on gender inequality theory - social perspective', Gender and Behaviour 2, 172-178.

Hendriks, H.J., 2004, Studying congregations in Africa, Lux Verbi.BM, Wellington.

Hogan, L.L., 2005, 'The individual in relation to public preaching', in A. Grösinger \& K.H. Soon (eds.), Preaching as shaping experience in a world of conflict, Studia Homiletica 5, Preaching as shaping experience in a world of conflict, pp. 100-108, Protea Book House, Pretoria.

Jones, S., 2000, Feministic Theory and Christian Theology, Fortress Press, Minneapolis.

Lose, D.J., 2003, Confessing Jesus Christ: Preaching in a Postmodern World, Wm.B.Eerdmans Publishing Co., Michigan.

Louw, D.J., 1998, A pastoral hermeneutics of care and encounter - A theological design for a basic theory, anthropology, method and therapy, Lux Verbi.BM, Cape Town.

Louw, D.J., 2009, 'Reframing masculainities and feministies in the gender debate: From the body as social text (narcissistic model tyranny) to the body as religious text (compassionate intimacy) in practical theology of human embodiment', in W. Grab \& L. Charbonnier (eds.), Secularization Theroies, Religious Identity and Practical Theology: Developing International Practical Theology for the 21st Century, pp. 293-340, Transaction Publishers, New Brunswick.

$\mathrm{Nel}, \mathrm{M} ., 2001$, Ek is die verskil, CLF Drukkers, Bloemfontein.

Nunes, C. \& Van Deventer, H.J.M., 2009, 'Feminist interpretation in the context of reformational theology: a consideration', In die Skriflig 43(4), 737-760.

Ohiott, P., Bhandary, A. \& Traveres, J., 2003, 'What women want. Comparing leadership challenges in Europe and the U.S.', Lia 23(3), 14-19.

Oliver, E., 2008, 'Vrouepredikante in die NederduitschHervormde Kerk van Afrika: 'n Opdraande stryd', Studia Historiae Ecclesiasticae XXIV, 213-233.

Osmer, R.R., 2008, Practical Theology: An introduction, Wm.B.Eerdmans Publishing Co., Michigan.

Steyn, C.S., 2008, "n Relasionele Hermeneutiek vir die Praktiese Teologie', Praktiese Teologie in Suid-Afrika 23(2), 248-268.

Sweazey, G.E., 1976, Preaching the Good News, Prentice-Hall, Inc., New Jersey.

Theron, J.P.J., 1989, 'Spiritualitiet en Pneumaitka: Konflik en aanvaarding binne Gereformeerde kringe in Suid-Afrika', Praktiese Teologie in Suid-Afrika 4(2).

Van Dam, G., 2005, Beyond expression: Approaching the Divine on spiritual guidance for an by pastors, Dutch Reformed Church, Lynwood Ridge. 